\title{
PROFESI PENDIDIK: TANTANGAN DAN HARAPAN
}

\author{
Nasrun \\ Universitas Negeri Medan, Jalan Willem Iskandar Pasar V Medan Sumatera Utara \\ Email: nasrun.nst@gmail.com
}

\begin{abstract}
Today's educational issues include two things, namely: (1) educational practice is conducted without education science; and (2) the occurrence of several "mistake" of education. The problem is of course influenced by several factors that are very complex, among others, there are five main things that cause two things can happen, namely: (1) educators are not trained in advance to carry out tasks (untrained); (2) not well trained (undertrained); (3) are less concerned about their duties and obligations (uncommitted); (4) lower education facilities (underfacilitated); and (5) educators are underpaid so as to give rise to pragmatic educational attitudes and burden objections. The provision that educators are professionals carries the consequence that educators are required to meet their professional requirements. Education Institution of Education Personnel (LPTK) as an institution producing educators and educational staff very concerned conceptually-praxis as the center of orientation and guidance for the development and enforcement trilogy educator profession, namely: (1) basic educational scholarship; (2) the substance of the educator profession; and (3) the practice of educator profession to be mastered by educator candidates. Along with the development of the dynamics and challenges of education increasingly complex. Policies and regulations that continue to be simulated and implemented are now directed to deal with various dynamics developments and challenges. The efforts of professionalization of educators through various programs are also continuously conducted. The efforts being undertaken and carried out at this time of hope in the future leads to the birth of educator figures in which awaken the professional dignity based on: (1) useful service; (2) a commensurate exercise; and (3) get a healthy recognition from the government and the community.
\end{abstract}

Keywords: profession, educator, professional, honorable

Abstrak: Permasalahan pendidikan dewasa ini mencakup dua hal, yaitu: (1) praktik pendidikan dilakukan tanpa didasari ilmu pendidikan; dan (2) terjadinya beberapa kecelakaan pendidikan. Permasalahan tersebut tentunya dipengaruhi oleh beberapa faktor yang sangat kompleks, antara lain ada lima hal pokok yang menyebabkan dua hal tersebut bisa terjadi, yaitu: (1) pendidik tidak dilatih terlebih dahulu untuk melaksanakan tugas-tugasnya (untrained); (2) tidak terlatih dengan baik (undertrained); (3) kurang peduli atas tugas dan kewajibannya (uncommitted); (4) fasilitas pendidikan rendah (under-facilitated); dan (5) pendidik dibayar rendah (underpaid) sehingga menimbulkan sikap pendidik yang pragmatis dan keberatan beban. Ketetapan bahwa pendidik adalah tenaga profesional membawa konsekuensi bahwa pendidik wajib memenuhi persyaratan profesionalnya. Lembaga Pendidikan Tenaga Kependidikan (LPTK) sebagai institusi penghasil pendidik dan tenaga kependidikan sangat berkepentingan secara konseptual-praksis sebagai pusat orientasi dan penuntun bagi pengembangan serta ditegakkannya trilogi profesi pendidik, yaitu: (1) dasar keilmuan pendidikan; (2) subtansi profesi pendidik; dan (3) praktik profesi pendidik yang harus dikuasi oleh calon pendidik. Seiring dengan perkembangan zaman dinamika dan tantangan dunia pendidikan semakin kompleks. Kebijakan dan regulasi yang terus digodok dan diimplementasikan saat ini diarahkan untuk menghadapi berbagai perkembangan dinamika dan tantangan yang terjadi. Upaya profesionalisasi pendidik melalui berbagai program juga terus dilakukan. Upaya-upaya yang sedang dilakukan dan dijalankan saat ini harapannya ke depan bermuara kepada lahirnya sosok-sosok pendidik yang di dalam dirinya terbangun kemartabatan profesi yang didasarkan atas: (1) pelayanan yang bermanfaat; (2) pelaksanaan yang bermandat; dan (3) mendapatkan pengakuan yang sehat dari pemerintah dan masyarakat.

Kata kunci: profesi, pendidik, professional, kemartabatan 
Dunia pendidikan sedang dan terus diuji dengan berbagai permasalahan yang terjadi. Melalui berbagai media massa cetak maupun elektronik belakangan ini sering diekspos peristiwa-peristiwa negatif yang terkait dengan wajah pendidikan di tanah air. Berita-berita negatif yang diekspos seperti bola liar yang meluncur dan siap menjadi santapan siapa saja. Pakar, pengamat, dan tokoh masyarakat, bahkan orang biasa yang tidak mendalami dan terlibat langsung dalam dunia pendidikan dengan bebasnya berkomentar yang nadanya juga sinis dan negatif. Jawaban yang klasik, mudah dan sering dikemukakan adalah kurikulum sering berganti, prasarana dan sarana kurang memadai, dan gaji guru rendah. Tanpa menolak jawaban tersebut menurut penulis ada hal-hal lain yang paling mendasar dan perlu mendapat perhatian. Prayitno (2009) menjelaskan bahwa tidak dipraktik-kannya ilmu pendidikan dan merajalelanya kecelakaan pendidikan merupakan dua hal yang mendasar yang menjadi akar rendahnya mutu pendidikan itu.

Terkait dengan kecelakaan pendidikan sudah bukan menjadi rahasia umum lagi bahwa selama ini sering terjadi di sekolah-sekolah kalau tidak membayar Sumbangan Penyelenggaraan Pendidikan (SPP) tidak boleh masuk sekolah, terlambat atau tidak mengerjakan pekerjaan rumah (PR) dihukum secara fisik, pelecehan dan penganiayaan terhadap peserta didik ataupun sebaliknya acap kali terjadi. Pendidikan tanpa ilmu pendidikan akan menyebabkan dunia pendidikan kian menurun. Prayitno (2009) menjelaskan ada lima hal pokok yang menyebabkan dua hal tersebut bisa terjadi, yaitu: (1) pendidik tidak dilatih terlebih dahulu untuk melaksanakan tugastugasnya (untrained); (2) tidak terlatih dengan baik (undertrained); (3) kurang peduli atas tugas dan kewajibannya (uncommitted); (4) fasilitas pendidikan rendah (under-facilitated); dan (5) pendidik dibayar rendah (underpaid) sehingga menimbulkan sikap pendidik yang pragmatis dan keberatan beban.

Disadari bahwa permasalahan yang mencerminkan mutu pendidikan sangatlah kompleks. Bagaikan mengurai benang kusut perlu keseriusan dan keuletan dalam mengatasinya. Dari sisi anggaran pendidikan, negara melalui aturan perundangundangan mangama-natkan bahwa dari total Anggaran Pendapatan dan Belanja Negera (APBN) mestilah dialokasikan sebesar 20\% belanja untuk pendidikan. Fakta dilapangan memang belum semua terpenuhi namun mestinya bukanlah hal tersebut menjadi alasan pokok mutu pendidikan belum berada pada level yang mapan. Perlu dipahami kembali bahwa dalam Undang-undang Nomor 20 Tahun 2003 tentang Sistem Pendidikan Nasional ditegaskan bahwa pendidik merupakan tenaga profesional yang bertugas merencanakan dan melaksanakan proses pembelajaran, menilai hasil pembelajaran, melakukan pembimbingan dan pelatihan, serta melakukan penelitian dan pengabdian kepada masyarakat, terutama bagi pendidik pada perguruan tinggi. Pendidikan merupakan suatu proses yang sangat strategis dalam mencerdaskan kehidupan bangsa, sehingga harus dilakukan secara profesional. Oleh sebab itu, pendidik haruslah seorang yang profesional, dengan demikian keberadaan pendidik di dalam pendidikan dapat bermakna bagi masyarakat dan bangsa. Kebermaknaan pendidik bagi masyarakat akan mendorong pada penghargaan yang lebih baik dari masyarakat kepada pendidik.

\section{PROFESIONALISASI PENDIDIK}

Pendidik profesional menjadi impian semua orang karena akan melahirkan anak bangsa yang cerdas, kritis, inovatif, demokratis, dan berakhlak. Pendidik profesional dan bermartabat memberikan teladan bagi terbentuknya kualitas sumber daya manusiayang kuat. Perwujudan impian ini bukanlah hal yang mudah, oleh karena itu diperlukan kerja keras dan kerjasama dari semua pihak, yaitu pemerintah pusat, pemerintah daerah, masyarakat, dan pendidik itu sendiri. Pendidik khususnya guru merupakan komponen utama terhadap terciptanya proses dan hasil pendidikan yang berkualitas. Oleh karena itu, upaya perbaikan apapun yang dilakukan untuk meningkatkan kualitas pendidikan tidak akan memberikan sumbangan yang signifikan tanpa didukung oleh guru yang profesional. Kinerja guru dalam pembelajaran merupakan faktor utama dalam proses pembelajaran dengan kata lain adanya peningkatan dalam mutu pendidikan tidak terlepas dari peran guru sebagai unsur utama dalam keseluruhan proses pendidikan. Guru mempunyai tugas untuk membimbing, mengarahkan dan juga menjadi teladan yang baik bagi para peserta didiknya. 
Upaya untuk menjadikan jabatan guru sebagai jabatan profesional telah dilakukan pemerintah melalui berbagai program yang memiliki landasan yuridis formal yang kuat, ini ditegaskan dalam Undang-undang Nomor 20 Tahun 2003 tentang Sistem Pendidikan Nasional. Dengan dipedomaninyaundang-undang tersebutdiharapkan dapat mewujudkan profesionalisasi jabatan guru yang pada akhirnya akan secara bertahap dapat meningkatkan mutu profesionalitas guru, sebagai bekal mendasar dalam kerangka peningkatan mutu pendidikan nasional secara menyeluruh. Secara normatif, Undang-undang Nomor 14 Tahun 2005 tentang Guru dan Dosen menandaskan dalam melaksanakan tugas keprofesionalan, guru berkewajiban: (1) merencanakan pembelajaran, melaksanakan proses pembelajaran yang bermutu, serta menilai dan mengevaluasi hasil pembelajaran; (2) meningkatkan dan mengembangkan kualifikasi akademik dan kompetensi secara berkelanjutan sejalan dengan perkembangan ilmu pengetahuan, teknologi, dan seni; (3) bertindak objektif dan tidak diskriminatif atas dasar pertimbangan jenis kelamin, agama, suku, ras, dan kondisi fisik tertentu, atau latar belakang keluarga, dan status sosial ekonomi peserta didik dalam pembelajaran; (4) menjunjung tinggi peraturan perundangundangan, hukum, dan kode etik guru, serta nilainilai agama dan etika; dan (5) memelihara dan memupuk persatuan dan kesatuan bangsa.

Peraturan Pemerintah Nomor 19 Tahun 2005 tentang Standar Nasional Pendidikan menjabarkan bahwa: (1) pendidik harus memiliki kualifikasi akademik dan kompetensi sebagai agen pembelajaran, sehat jasmani dan rohani, serta memiliki kemampuan untuk mewujudkan tujuan pendidikan nasional; (2) kualifikasi akademik sebagaimana dimaksud pada ayat (1) adalah tingkat pendidikan minimal yang harus dipenuhi oleh seorang pendidik yang dibuktikan dengan ijazah dan/atau sertifikat keahlian yang relevan sesuai ketentuan perundang-undangan yang berlaku; (3) Kompetensi sebagai agen pembelajaran pada jenjang pendidikan dasar dan menengah serta pendidikan anak usia dini meliputi: (a) kompetensi pedagogik; (b) kompetensi kepribadian; (c) kompetensi profesional; dan (c) kompetensi sosial; (4) seseorang yang tidak memiliki ijazah dan/atau sertifikat keahlian sebagaimana dimaksud pada ayat
(2) tetapi memiliki keahlian khusus yang diakui dan diperlukan dapat diangkat menjadi pendidik setelah melewati uji kelayakan dan kesetaraan; (5) kualifikasi akademik dan kompetensi sebagai agen pembelajaran sebagaimana dimaksud pada ayat (1) sampai dengan (4) dikembangkan oleh BSNP dan ditetapkan dengan Peraturan Menteri. Pandangan yang ideal mengenai profesionalisme guru, direfleksikan dalam citra guru masa depan sebagaimana dikemukakan oleh Sudarminta (1990), yaitu guru yang: (1) sadar dan tanggap akan perubahan zaman; (2) berkualifikasi profesional; (3) rasional, demokratis dan berwawasan nasional; dan (4) bermoral tinggi, beriman.

Guru adalah pendidik profesional dengan tugas utama adalah mendidik, mengajar, membimbing, mengarahkan, melatih, menilai, dan mengevaluasi peserta didik pada pendidikan anak usia dini jalur pendidikan formal, pendidikan dasar dan pendidikan menengah. Undang-undang Nomor 20 Tahun 2003 tentang Sistem Pendidikan Nasional, dalam konsiderannya, menjelaskan bahwa guru professional harus memiliki kualifikasi minimum dan sertifikasi sesuai dengan jenjang kewenangan mengajar, sehat jasmani dan rohani, serta memiliki kemampuan untuk mewujudkan tujuan pendidikan nasional. Hal ini diperkuat oleh Undang-undang Nomor 14 Tahun 2005 tentang Guru dan Dosen dan Peraturan Pemerintah Nomor 19 Tahun 2005 tentang Standar Nasional Pendidikan yang menjelaskan bahwa guru wajib memiliki kualifikasi akademik, kompetensi, sertifikat pendidik, sehat jasmani dan rohani, serta memiliki kemampuan untuk mewujudkan tujuan pendidikan nasional.

Guru dituntut untuk profesional dengan memiliki kompetensi pedagogik, kepribadian, sosial dan profesional. Cara mendapatkan guru seperti kriteria di atas melalui kualifikasi, uji kompetensi dan sertifikasi. Dengan demikian guru profesional harus memiliki sertifikat profesi. Sertifikasi diberikan secara individual kepada Pendidik sebagai pengakuan atas kompetensinya dalam keahlian dan keterampilan kependidikan juga sebagai lisensi untuk melakukan pekerjaan Pendidik. Sertifikasi mempunyai jenjang dari tingkat dasar sampai ahli dengan masa berlaku sesuai ketentuan dan perlu pendaftaran pada setiap kurun waktu tertentu sesuai dengan sistem 
yang diberlakukan. Sertifikasi merupakan proses pengambilan keputusan kelayakan individu dalam jabatantertentu. Proses tersebut terdiri darikegiatan: (1) pengujian, yaitu mengukur tingkat kompetensi pendidik yang ditetapkan berdasarkan standar kompetensi pendidik; (2) pendidikan profesi; diberikan kepada pendidik untuk memperoleh sertifikasi yang diselenggarakan oleh Lembaga Pendidikan Tenaga Kependidikan (LPTK) yang terakreditasi dan ditetapkan oleh pemerintah; dan (3) penetapan sertifikat, diperoleh setelah mengikuti pendidikan profesi dan dinyatakan lulus pendidikan profesi dan uji kompetensi.

Sertifikasi bertujuan untuk: (1) mencetak calon pendidik qualified dalam melaksanakan tugas pokok fungsi pendidik untuk meningkatkan kualitas sekolah; (2) menentukan tingkat kelayakan pendidik dalam menyelenggarakan layanan pendidikan; dan (3) memperoleh gambaran tentang kompetensi pendidik yang dapat digunakan sebagai alat pembinaan, pengembangan, dan peningkatan kualitas pendidikan. Fungsi sertifikasi adalah untuk: (1) untuk pengetahuan, yakni dalam rangka mengetahui bagaimana kelayakan kompetensi Pendidik dilihat dari berbagai unsur yang terkait, mengacu kepada baku kualitas yang dikembangkan berdasarkan indikator-indikator yang telah ditentukan; (2) untuk akuntabilitas, yakni agar pendidik dapat mempertanggungjawabkan apakah layanan yang diberikan memenuhi harapan atau keinginan masyarakat; dan (3) untuk kepentingan pengembangan, yakni agar pendidik dapat melakukan peningkatan kualitas atau pengembangan berdasarkan masukan dari hasil sertifikasi.

\section{PERAN LEMBAGA PENDIDIKAN TENAGA KEPENDIDIKAN}

LPTK sebagai lembaga/institusi penghasil pendidik dan tenaga kependidikan memiliki peranan yang sangat vital dalam upaya menghasilkan tenaga pendidik khususunya guru yang professional. Sebelum diberlakukannya Undang-undang Nomor 14 Tahun 2005 tentang Guru dan Dosen, profesi guru bersifat tertutup artinya mereka yang tidak berlatar belakang pendidikan dari LPTK sulit untuk diterima menjadi guru. Profesi guru hanya terbatas bagi mereka lulusan LPTK. Dengan kata lain LPTK merupakan lembaga satu-satunya yang bertanggung jawab mempersiapkan dan menghasilkan tenaga pendidik. Di samping itu sebelum diberlakukannya UU tersebut, latar belakang pendidikan seseorang calon guru tidak harus sarjana (S1) atau D IV. Namun sejak diberlakukannya Undang-undang Nomor14 Tahun 2005 tentang Guru dan Dosen, seseorang yang akan menjadi guru tidaklah harus berasal dari LPTK, sebagaimana disebutkan di Undang-undang Nomor14 Tahun 2005 tentang Guru dan Dosen pasal 12 bahwa setiap orang yang telah memperoleh sertifikat pendidik memiliki kesempatan yang sama untuk diangkat menjadi guru pada satuan pendidikan tertentu. Dengan demikian pasal tersebut mengisyaratkan bahwa saat ini profesi guru merupakan profesi yang terbuka, artinya siapa saja dapat menjadi guru asalkan memenuhi persyaratan memiliki sertifikat pendidik dan minimal S1 atau D IV, fakta ini berdampak terhadap peranan LPTK selanjutnya.

Secara umum ada dua fungsi LPTK yaitu: (1) LPTK yang fungsinya hanya menyelenggarakan pendidikan prajabatan; dan (2) LPTK yang hanya menyelenggarakan pendidikan dalam jabatan (Natawidjaya, 1992). Lebih lanjut Natawidjaja (1993) menyebutkan ada LPTK yang bertugas menghasilkan guru TK, SD, SMP, SMA, dan ada LPTK yang khusus bertugas menyediakan guru untuk jenis sekolah tertentu atau bidang studi misalnya guru pendidikan luar biasa atau guru olahraga kesehatan. Dengan kata lain tugas pokok LPTK adalah menyelenggarakan pendidikan untuk calon tenaga kependidikan untuk semua jenjang pendidikan serta keahliannya.

Berdasarkan tujuan umum, dirinci tujuan secara khusus yang bersifat operasional, yaitu: (1) menghasilkan guru SD, SMP dan SMA yang bermutu dan meliputi berbagai bidang studi sesuai dengan kebutuhan; (2) menghasilkan tenaga kependidikan lain yang menunjang berfungsinya sistem pendidikan, seperti petugas administrasi pendidikan, petugas bimbingan dan konseling, pengembang kurikulum dan teknologi pendidikan, petugas pendidikan luar sekolah, dan lain-lain sesuai dengan ketentuan sistem; (3) menghasilkan tenaga ahli pendidik dalam membagi bidang studi, yang mampu memenuhi kebutuhan tenaga pendidik/instruktur bagi lembaga pendidikan pemerintah maupun swasta; (4) menghasilkan 
ilmuan/peneliti dalam ilmu pendidikan baik bidang studi maupun bidang pendidikan lainnya; (5) mengembangkan ilmu, teknologi dan seni kependidikan untuk menunjang praktek profesional kependidikan; (6) mempersiapkan dan membina tenaga akademik untuk LPTK, sesuai dengan kebutuhan; (7) mengembangkan dan melaksanakan program pendidikan dalam jabatan (in-service) untuk tenaga kependidikan; (8) melayani usaha perbaikan dan pengembangan aparat pengelola pendidikan sesuai dengan pengembangan ilmu, metodologi dan teknologi serta seni kependidikan; (9) melaksanakan penelitian dalam bidang kependidikan, baik pendidikan formal maupun pendidikan nonformal dan informal; dan (10) melaksanakan program pengabdian pada masyarakat, yang berhubungan dengan masalahmasalah kependidikan (Natawidjaya, 1993).

Selama ini dikenal ada dua model penyelenggaraan pendidikan guru yaitu concurrent model dan consecutive model. Concurrent model yaitu suatu model penyelenggaraan pendidikan guru yang menyiapkan calon guru yang dilakukan dalam satu napas, satu fase, antara penguasaan bidang studinya (subject matter) dengan kompetensi pedagogi (ilmu pendidikan). Model inilah yang dipakai selama lebih dari 50 tahun dalam penyelenggaraan pendidikan guru di Indonesia. PTPG, FKIP, IKIP, SGB, SGA, SPG, SGO, PGA, sebagai bentuk LPTK yang pernah ada di Indonesia menggunakan model ini.

Model ini mengasumsikan bahwa seorang calon guru sejak awal sudah mulai memasuki iklim, menjiwai, menyadari akan dunia profesinya. Seorang guru tidak hanya dituntut menguasai bidang studi yang akan diajarkannya, melainkan juga kompetensi pedagogi, sosial, akademik, dan kepribadian sebagai pendidik. Kompetensi tersebut bukan sesuatu yang terpisah, melainkan jadi ramuan komposisi yang khas yang dijiwainya. Kalau guru diasumsikan sebagai petugas profesional, harus disiapkan secara profesional, secara sengaja untuk jadi guru, juga di lembaga yang sengaja dibuat dan dipersiapkan untuk mendidik calon guru. Kritik terhadap model ini, penguasan subject matter (bidang ilmu) dianggap lemah karena perolehan kemampuan bidang ilmu yang diajarkannya dianggap kurang dari sarjana bidang ilmu (murni). Ini dianggap kelemahan dan dinisbahkan sebagai salah satu faktor yang menyebabkan rendahnya kompentensi guru yang selama ini dipersipkan di LPTK.

Asumsi yang dipakai dalam model consecutive model (pendekatan berlapis) menghendaki penyiapan guru dilakukan dalam napas atau rangkaian yang berbeda. Artinya, calon guru sebelumnya tidak dididik dalam setting LPTK. Mereka adalah para sarjana bidang ilmu, kemudian setelah itu menempuh pendidikan lanjutan di LPTK untuk memperoleh akta kependidikan yang selama ini diposisikan sebagai lisensi profesi guru. Model ini menghendaki sarjana dulu di bidangnya kemudian mengikuti pendidikan akta kependidikan sebagai sertifikasi profesi kependidikan. Keunggulan model ini dianggap memiliki penguasaan bidang studi lebih baik unggul, tetapi lemah dari aspek kompetensi ilmu pendidikan (pedagogis), sosial, dan kepribadian sebagai calon guru. Dalam pola ini penyiapan subject matter dengan kompetensi pedagogi, sosial, dan kepribadian adalah hal yang berbeda, bukan desain pendidikan profesional yang terpadu.

Sejak diberlakukannya Undang-undang Nomor14 Tahun 2005 tentang Guru dan Dosen, nampaknya penyelenggaraan pendidikan guru saat ini cenderung dilakukan dengan menggunakan concecutive model, ini dapat dilihat pada 12 yang menyatakan setiap orang yang telah memperoleh sertifikat pendidik memiliki kesempatan yang sama untuk diangkat menjadi guru pada satuan pendidikan tertentu. Salah satu dampak nya adalah meningkatnya minat dan apresiasi masyarakat terhadap profesi guru. Disamping itu, Undangundang Nomor14 Tahun 2005 tentang Guru dan Dosen menggariskan bahwa profesi guru minimal berpendidikan S-1 atau D-4, baik kependidikan maupun nonkependidikan. Hal ini mengisyaratkan bahwa profesi guru merupakan profesi yang bersifat terbuka, bukan hanya bagi lulusan dari LPTK, melainkan pula dari non-LPTK. Peranan LPTK sebagai lembaga penyelenggara program pendidikan bagi calon guru yang pada akhirnya diharapkan mewujudkan guru yang profesional mendapat tantangan, betapa tidak dengan diberlakukannya Undang-undang Nomor14 Tahun 2005 tentang Guru dan Dosen, setiap orang yang memiliki sertifikat pendidik, memiliki kesempatan yang sama untuk diangkat menjadi guru pada satuan 
pendidikan tertentu. Dengan demikian profesi guru menjadi profesi yang terbuka, artinya mereka yang diterima menjadi guru tidak harus lulusan LPTK. Ini berarti bahwa peluang untuk menjadi guru bagi lulusan LPTK menjadi berkurang, sebab harus bersaing dengan mereka yang berasal dari nonLPTK. Jika tidak diantisipasi oleh LPTK, maka akan ada kemungkinan suatu saat eksistensi LPTK menjadi hilang. Namun di lain pihak, masih ada harapan yang ditujukan kepada LPTK sebagai lembaga pencetak guru yaitu hendaknya dapat senantiasa meningkatkan peranannya sehingga dapat mewujudkan guru yang profesional.

Ketentuan pada Undang-undang Nomor 23 Tahun 2003 tentang Sistem Pendidikan Nasional tentang definisi profesional sebagaimana dikutip pada Bab II terdahulu, memberikan pemahaman bahwa di dalam konsep profesional terkandung hal-hal: (1) suatu pekerjaan atau kegiatan; (2) menjadi sumber penghasilan untuk kehidupan; (3) memerlukan keahlian, kemahiran atau kecakapan; (4) memenuhi standar mutu atau norma tertentu; dan (5) memerlukan pendidikan profesi. Dengan kandungan demikian itu, suatu profesi harus benar-benar dipersiapkan dan dibina dengan sebaik-baiknya, dalam hal ini melalui pendidikan profesi dan sarana pembinaan lainnya, sehingga menjadi profesi yang benar-benar bermartabat. Prayitno (2011) menegaskan bahwa keseluruhan ciri dan isi suatu profesi ke dalam tiga komponen trilogi profesi pendidik adalah: (1) dasar keilmuan penididkan; (2) substansi profesi pendidik; dan (3) praktik profesi pendidik. Komponen dasar keilmuan menyiapkan (calon) tenaga profesional pendidik dengan landasan dan arah tentang wawasan, pengetahuan, keterampilan, nilai, dan sikap (WPKNS) berkenaan dengan profesi pendidik. Komponen substansi profesi pendidik memberikan modal tentang apa yang menjadi fokus dan objek praktik spesifik profesi pendidik dengan bidang khusus kajiannya, aspek-aspek kompetensi, sarana operasional dan manajemen, kode etik, serta landasan praktik operasional. Komponen praktik profesi pendidik merupakan realisasi pelaksanaan pelayanan profesi pendidik setelah kedua komponen profesi (dasar keilmuan dan subtansi profesi) dikuasai.

Ketiga komponen trilogi profesi pendidik merupakan satu kesatuan tak terpisahkan; ketiganya merupakan kesatuan, dan dipelajari dengan intensif sehingga menghasilkan keterampilan keahlian yang tinggi atau bahkan sangat tinggi mengacu kepada standar norma atau standar mutu tertentu. LPTK sebagai lembaga formal sudah semestinyalah memiliki fokus yang tinggi dalam program pendidikannya sebab penguasaan dan penyelenggaraan trilogi profesi pendidik yang dimaksudkan itu secara mantap dan konsisten merupakan jaminan bagi suksesnya penampilan profesi pendidik demi kebahagiaan sasaran pelayanan.

\section{KEMARTABATAN PROFESI PENDIDIK}

Apabila ketiga komponen trilogi profesi pendidik telah terbina dan teraplikasikan dengan baik, maka suatu profesi semestinyalah menjadi profesi yang bermartabat. Prayitno (2012) menjelaskan bahwa kemartabatan yang dimaksudkan itu meliputi kondisi:

\section{Pelayanan Bermanfaat}

Pelayanan profesional yang diselenggarakan benar-benar bermanfaat bagi kemaslahatan kehidupan secara luas. Upaya pelayanan yang diimplikasikan oleh para pemegang suatu profesi, apalagi profesi pendidik yang bersifat formal dan diselenggarakan berdasarkan aturan perundangan seperti profesi pendidik, tidak boleh sia-sia, apalagi terselenggara dengan cara-cara yang salah (malpraktik), melainkan terlaksana dengan manfaat yang setinggi-tingginya bagi sasaran pelayanan dan pihak-pihak lain yang terkait.

\section{Pelaksana Bermandat}

Pelayanan profesional diselenggrakan oleh petugas atau pelaksana yang bermandat. Sesuai dengan sifatnya yang profesional itu, maka pelayanan yang dimaksud haruslah dilaksanakan oleh tenaga yang benar-benar dipercaya untuk menghasilkan tindakan dan produk-produk pelayanan dalam mutu yang tinggi. Program pendidikan sarjana dan profesi yang terpadu serta sinambung dalam rangka trilogi profesi pendidik merupakan sarana dasar dan esensial untuk menyiapkan pelaksana yang dimaksudkan itu. Dengan demikian Lulusan LPTK diharapkan benar-benar menjadi tenaga profesional handal 
yang layak memperoleh kualifikasi bermandat, baik dalam arti akademik, kompetensi, maupun posisi pekerjaannya.

\section{Pengakuan Sehat}

Pelayanan profesional yang dimaksudkan itu diakui secara sehat oleh pemerintah dan masyarakat. Dengan kemanfaatan yang tinggi dan dilaksanakan oleh pelaksana yang bermandat, pemerintah dan masyarakat tidak ragu-ragu mengakui dan memanfaatkan pelayanan yang dimaksudkan itu. Peraturan perundangan telah secara umum menyatakan pentingnya keprofesionalan tenaga pendidik, yang selanjutnya mudah-mudahan dilanjutkan dengan pengakuan yang sehat atas lulusan program pendidikan profesi pendidik dan pelayanan yang mereka praktikkan. Demikian juga masyarakat diharapkan memberikan pengakuan secara terbuka melalui pemanfaatan dan penghargaan yang tingi atas profesi pendidik tersebut.

\section{DAFTAR RUJUKAN}

Natawidjaya, R. 1992. Peningkatan Kualitas Profesional Guru Sekolah Dasar melalui Pemantapan Lembaga Kependidikannya. Jurnal Pendidikan, 11(1), 12-19.

Peraturan Pemerintah Nomor 19 Tahun 2005 tentang Standar Nasional Pendidikan. 2006. Bandung: Citra Umbara.

Prayitno. 2009. Dasar, Teori, dan Praksis Pendidikan. Jakarta: Grasindo.

Prayitno. 2011. Membangung Filsafat dan Ilmu Pendidikan. Jakarta: Grasindo.

Undang-undang 14 Tahun 2005 tentang Guru dan Dosen. 2006. Bandung: Citra Umbara.

Undang-undang Nomor 20 Tahun 2003 tentang Sistem Pendidikan Nasional. 2006. Bandung: Citra Umbara. 